Social Work \& Education $\begin{array}{ll}\text { and } \\ 10.2512821252020 .6230 .192 .7\end{array}$
UDC 159.942.5-054.72-044.332

DOI: $10.25128 / 2520-6230.19 .2 .7$
Vasylkevych, Ya. (2019). Features of social and pedagogical work with military personnel, Social Work and Education, Vol. 6, No. 2, pp. 186-195. DOI:

(๑) SW\&E, 2019

Yaroslava Vasylkevych,

$\mathrm{PhD}$ in Psychology,

Associate Professor of the

Department of Psychology,

SHEI «Pereiaslav-Khmelnytskyi

Hryhorii Skovoroda State

Pedagogical University»

30, Sukhomlynsky Street,

Pereiaslav-Khmelnytskyi, Ukraine, 08401

v.yaroslava@online.ua

ORCID: 0000-0002-5946-3005
Article history:

Received: March 09, 2018

1st Revision: April 02, 2019

Accepted: June 30, 2019

\section{DIAGNOSTICS OF}

PSYCHOLOGICAL PECULIARITIES OF EMOTIONAL ATTITUDES OF AN INTERNALLY DISPLACED PEOPLE
Abstract. The article deals with a theoretically determined the psychological component of the adaptation of forced migrants. Individual and group factors of social and psychological adaptation are characterized. The influence on the adaptation of subjective attitudes as an integrated personal characteristic of migrants is substantiated. The methodology of colour metaphors is developed and adapted for the diagnostics of internally displaced people (IDPs). The psychological peculiarities of the system of emotional attitudes of IDPs are empirically investigated. The gender specificity of the structure of the attitudes of forced migrants is determined (men have higher levels of emotional stability and self-esteem, they are more satisfied with business relations and focus on activities; women are satisfied with relationships in the informal sphere and more focused on the family).

Keywords: internally displaced persons; social and psychological adaptation; emotional attitudes. 


\section{Introduction}

The number of IDPs in Ukraine is 1,5 million persons in late 2018 year. The largest number of migrants lives in unoccupied territories of the Donbas: 550 thousand people - in Donetsk region, 287 thousand - in Luhansk region. The National monitoring system regularly gathers, processes and shares information on the situation in the field of the population movement, which provides a better understanding of the moving process, social and economic characteristics of IDPs, and challenges faced by them (National Monitoring System Report..., 2018).

The Law of Ukraine "On Ensuring of Rights and Freedoms of Internally Displaced Persons" guarantees psychological and social support for forced migrants. One of the most urgent challenges for IDPs is to simplify the process of social and psychological adaptation and to attract them to a full livelihood in a new social environment.

The determination of the psychological factors of increasing the subjective wellbeing of forced migrants is a prerequisite for improving the social and psychological work on the adaptation of IDPs to the current conditions of Ukrainian society. Important factors in the process of adaptation of IDPs are the normalization of their psychological and emotional state; the overcoming of stress disorders during the difficult adaptation period through the identification and involvement of all personal resources. Therefore, psychologists have the task to develop a comprehensive social and psychological programme of the adaptation of IDPs to the modern conditions of Ukraine.

The problem of social and psychological adaptation of forced migrants has been studied by foreign and native researchers (I. Babiker, R. Linton, J. Marcia, D. Matsumoto, K. Oberg, M. Herskovitz, L. Balabanova, O. Blynova, V. Pavlenko, H. Soldatova, M. Shulha, V. Hrytsenko, and others). The studies on social and psychological work with IDPs are relevant for countries that have experienced military conflicts and faced with the need to solve negative after-effect. Theoretical frameworks of the problem of migration processes in the psychology relate to the problems of acculturation (J. Barry, S. Bochner) and the psychological adaptation of migrants to another social and cultural environment (M. Sliusarevskyi, O. Blynova, L. OrbanLembryk); analysis of the situation of forced migration (B. Hrytsenko, H. Soldatova, I. Chenbay, M. Shulha) and methods of rehabilitation of people with post-traumatic stress (H. Lazos, N. Maksymova, T. Tytarenko).

According to A. Furnham's and S. Bochner's studies, the social and psychological adaptation of temporarily displaced people has its peculiarities: such people don't worry about differences; and the behavioral skills, which they gain in another social and cultural environment, are reversible (Furnham, Bochner, 1994).

M. Sliusarevskyi and O. Blynova have analyzed individual factors that determine the peculiarities of adaptation of migrants: social and demographic characteristics (gender, age, education, legal status); personal characteristics (cognitive, motivational, communicative and emotional); life experience (knowledge of language, local customs, traditions and norms; knowledge of the employment possibility, migration experience, social support) (Slyusarevsky, Blynova, 2013).

Despite the different negative factors that affect the social and psychological adaptation of the forced migrant; there are factors that positively affect its adaptation: previous adaptive experience (change of workplace, moving into a new house, etc.); education (not only a diploma, but also the level of development of abilities, skills, 
readiness to study, etc.); self-identified in a new environment; life goals and motivation (Leonova, 2015).

At the same time, the problem of psychological support of IDPs is new and unexplored by native scientists, which causes realization of further study in this field, in particular, a study of the individual attitude as an indicator of the psychological wellbeing of forced migrants.

The article aims at theoretically justify and empirically investigate the peculiarities of the emotional attitudes of IDPs to various aspects of reality. The study includes the following tasks: conducting a theoretical analysis of the psychological component of the adaptation of forced migrants and the justify of its influence on the adaptation of subjective attitudes as integral personal characteristics of migrants; and studying psychological peculiarities of the system of emotional attitudes of IDPs with the indicating gender specifics.

\section{Methodology of the Research}

Theoretical analysis of the problem of psychological adaptation of forced migrants makes it possible to highlight its peculiarity in our country - cultural and psychological relationships between IDPs and host communities: they are well-informed about culture and language, but the social and cultural environment is very different, which requires the ability to form new social connections. In the process of social and psychological adaptation of these persons, an important condition is the accordance of socially regulated behavior with interests, value orientations of the IDPs and, the same time, the processes of integration in the society without losing of personality. Indicators of adaptability of IDPs include social comfort; active inclusion to the activity of the host community, activity in achieving the goals; optimism (understanding the possibility of realizing their own goals in the future) (Blynova, 2017).

A. Furnham and S. Bochner have developed a theory of social and psychological support for IDPs, which prevents various types of mental disorders and, as a result, provides a high level of subjective well-being. It is proved that for displaced people, at the beginning of their entry into another culture, information support is the most valuable and necessary, later - instrumental support, and finally - emotional support. At the same time, emotional support plays a special role in the process of social and psychological adaptation; because it is the most effective in the situation of counteracting the influence of different stress factors (Furnham, Bochner, 1994).

M. Sliusarevskyi and O. Blynova divide personal characteristics that determine the success of the adaptation of migrants into the following groups: cognitive, motivational, communicative and emotional (Sliusarevskyi, Blynova, 2013, p. 191). Integrator of all personal characteristics is the personal attitudes, which ensures the integrity, stability, depth, and consistency of his/her behavior. The higher is the level of personal development more difficult processes of mental activity, differentiated and richer his/her attitude. "Subjective attitudes of personality" (B. Lomov) as the integral personal characteristics, demonstrate what a person thinks about some events and phenomena of the world in which he/she lives. Subjective attitudes affect all mental processes, especially in emotional tone. Attitudes, as a structure-forming kind of psychic phenomena, determine the activity of the personality. The essence of the personality is determined by his/her attitudes to the environment, social being, other people and themselves. Personal activity means that these attitudes are realized in the 
activities of people. Personal attitudes play a regulatory role in his/her behavior; affect the formation of the inner world of personality, mental processes - cognitive, volitional, and emotional.

In our study, the peculiarities of emotional attitudes of IDPs to various aspects of reality have been empirically investigated. The modified projective methodology of colour metaphors by E. Solomin (2008) has been used for the studying the specificity of the system of attitudes of forced migrants to various aspects of reality (to himself/herself, other people, various activities). This methodology included the method of colour choices by Sobchyk (modification of the Liuscher test). The rating for the processing and interpretation of obtained data has been used.

The methodology of colour metaphors has been adapted to the sample of IDPs: in addition to key concepts, we selected concepts that allow diagnosing the specifics of attitudes and motives of migrants. Thus, a list included 60 concepts that were relevant to the main types of activities, needs, vital values and emotional experiences of forced migrants.

The analysis of the results has been based on two principles:

1) the concepts, marked in the most attractive colour, were characterized by the most positive attitude to IDPs (what respondents like best); and vice versa, the concepts, marked in the most unpleasant colour were characterized as the most negative attitudes (what respondents avoid);

2) a few words, marked in the same colour, were characterized as a similarity of emotional attitudes to them; in these words there was something common for respondents; there was a connection or association between such concepts in their consciousness.

The empirical study included sample of IDPs from Luhansk region. There were 25 people (14 men and 11 women) 18-30 year-olds who leaved their home because of the armed conflict on their territory.

\section{Results}

The analysis of rating of concepts shows that the highest average rating and ranking positions have the concept "My home" $(\Sigma=2,6 ; \mathrm{R}=1)$; "Optimism" $(\Sigma=2,64$; $\mathrm{R}=2)$, "Joy" $(\Sigma=2,92 ; \mathrm{R}=5)$, "Real I" $(\Sigma=2,92 ; \mathrm{R}=5)$; "Ideal I" $(\Sigma=2,96 ; \mathrm{R}=7)$; "Confidence" $(\Sigma=3,4 ; \mathrm{R}=8)$; "Guarantees" $(\Sigma=3,8 ; \mathrm{R}=9,5)$; "Financial well-being" $(\Sigma=3,8 ; \mathrm{R}=9,5)$ (Table 1). This means the positive attitude of IDPs to these concepts, confidence in their capabilities and the aspiration to self-realization.

Key concepts "Politics" $(\Sigma=6 ; \mathrm{R}=58)$; "War" $(\Sigma=5,88 ; \mathrm{R}=56)$; "Displacement" $(\Sigma=5,32 ; \mathrm{R}=53)$ have the lowest average ratings and ranked places, which are accompanied by negative emotional states: "Pain" $(\Sigma=6,44 ; \mathrm{R}=60)$; "Anxiety" $(\Sigma=5,52 ; \mathrm{R}=57)$; "Loneliness" ( $(=5,64 ; \mathrm{R}=55)$, "Threat" $(\Sigma=5,48 ; \mathrm{R}=54)$, "Fear" $(\Sigma=5,28 ; \mathrm{R}=51,5)$.

The analysis of the results has been carried out using a table of the similarities of concepts that were marked in the same colour. Indicator of the degree of similarity between the concepts is the percentage of respondents who indicated these concepts in the same colour. In the process of analysis, concepts have been considered as similar, if not less than $1 / 3$ of the respondents in a group marked them in the same colour. Thus, tables of similarity of concepts for results of diagnosis among the general sample, men's and women's sample were obtained (Table 2). 
Rating of concepts by IDPs

\begin{tabular}{|l|l|l|l|l|l|}
\hline & \multicolumn{1}{|c|}{$\sum$} & \multicolumn{1}{|c|}{$\mathbf{R}$} & & $\sum$ & \multicolumn{1}{|c|}{$\mathbf{R}$} \\
\hline My home & 2,6 & 1 & Irritation & 4,04 & 31 \\
\hline Optimism & 2,64 & 2 & Adaptation & 4,48 & 32 \\
\hline Love & 2,72 & 3 & Social support & 4,52 & 33,5 \\
\hline Joy & 2,92 & 5 & My past & 4,52 & 33,5 \\
\hline Who I am in reality & 2,92 & 5 & Risk-taking & 4,56 & 35,5 \\
\hline Interesting tasks & 2,92 & 5 & Psychological support & 4,56 & 35,5 \\
\hline Who I want to be & 2,96 & 7 & Fail & 4,64 & 37 \\
\hline Confidence & 3,4 & 8 & Medical care & 4,68 & 38 \\
\hline Guarantees & 3,8 & 9,5 & My present & 4,76 & 39,5 \\
\hline Financial well-being & 3,8 & 9,5 & Power & 4,76 & 39,5 \\
\hline Children & 3,04 & 11 & Army & 4,84 & 41,5 \\
\hline My passion & 3,08 & 12 & Aggressiveness & 4,84 & 41,5 \\
\hline Recognition by others & 3,16 & 13,5 & Study & 4,92 & 43 \\
\hline Communication & 3,16 & 13,5 & Legal advice & 5,2 & 44,5 \\
\hline Self-respect & 3,36 & 15 & Information & 5,2 & 44,5 \\
\hline Reliability & 3,44 & 16,5 & Sadness & 5,6 & 46 \\
\hline My future & 3,44 & 16,5 & Aggressor & 5,04 & 47 \\
\hline My career & 3,48 & 18,5 & Insult & 5,6 & 48,5 \\
\hline Trust & 3,48 & 18,5 & Uncertainty & 5,6 & 48,5 \\
\hline Financial support & 3,56 & 20,5 & My family & 5,24 & 50 \\
\hline Safety & 3,56 & 20,5 & Troubles & 5,28 & 51,5 \\
\hline Tolerance & 3,64 & 22 & Fear & 5,28 & 51,5 \\
\hline Earnings & 3,72 & 23,5 & Displacement & 5,32 & 53 \\
\hline Freedom & 3,72 & 23,5 & Threat & 5,48 & 54 \\
\hline Money & 3,84 & 25 & Loneliness & 5,64 & 55 \\
\hline Stability & 3,88 & 26 & War & 5,88 & 56 \\
\hline Creativity & 3,92 & 27,5 & Anxiety & 5,92 & 57 \\
\hline Changes & 3,92 & 27,5 & Politics & 6 & 58 \\
\hline Job (occupation) & 3,96 & 29 & Disease & 6,12 & 59 \\
\hline Household & 4,4 & 30 & Pain & 6,44 & 60 \\
\hline & & & & & \\
\hline
\end{tabular}

The following groups of similar concepts among the general sample of IDPs have been revealed:

- 36\% of the respondents marked the concepts "My future", "Who I want to be", "Financial well-being", "Financial support", "Legal advice" in green colour;

- 40\% of the respondents marked the concept "Aggressor" in red colour;

- the concepts "Social support" (36\%), "Displacement" and "Medical care" (40\%), "Politics" (48\%), "Uncertainty" (56\%) were marked in grey colour;

- the concepts "War" (60\%), "Threat" (48\%) and "Fear" (52\%) were marked in black colour. 
Table 2

Groups of similar concepts marked in the same colour among the sample of IDPs

\begin{tabular}{|c|c|c|}
\hline Concepts & Colour & Percentage of respondents \\
\hline My future & 2 & $36 \%$ \\
\hline Financial support & 2 & $36 \%$ \\
\hline Legal advice & 2 & $36 \%$ \\
\hline Financial well-being & 2 & $36 \%$ \\
\hline Who I want to be & 2 & $36 \%$ \\
\hline Aggressor & 3 & $40 \%$ \\
\hline Medical care & 0 & $40 \%$ \\
\hline Displacement & 0 & $40 \%$ \\
\hline Social support & 0 & $36 \%$ \\
\hline Politics & 0 & $48 \%$ \\
\hline Uncertainty & 0 & $56 \%$ \\
\hline Fair & 7 & $52 \%$ \\
\hline Threat & 7 & $48 \%$ \\
\hline War & 7 & $60 \%$ \\
\hline
\end{tabular}

\section{Discussion}

The system of respondents' attitudes to different aspects of reality has been described below. In the structure of attitudes, one of the most important characteristics is the attitude to their future, themselves, different activities, and key concepts for migrants such as "Displacement", "War", etc.

The attitude to the future is characterized by expectations, hopes, intentions, plans, and ideas about what can happen with a person, what he/she will do. The respondents marked the concept "My future" (36\%) and "Who I want to be" (36\%) in green colour, which means that the IDPs is oriented on the future, they want self-development and ready for positive changes. The concept "My future" is associated with "Financial well-being" (36\%), "Financial support" (36\%), "Legal advice" (36\%) that means that respondents have a lack of funding so far, but expect, that their financial and social status will be changed in the future. They adapt more actively to their new home, work or study, plan their future and want stability.

At the same time, respondents didn't mark the concepts "My past" and "My present" in similar colours, which means that these periods are different for them.

The concepts "Displacement" (40\%) and "Politics" (48\%) have been marked in grey colour. It is a direct connection between these concepts because respondents associate their displacement with political reason. Marking the concepts "Social assistance" (36\%) and "Medical care" (40\%) with the concept "Uncertainty" (56\%) in one colour causes the feelings of confusion, uncertainty, and anxiety. The IDPs don't get the necessary social support and medical care; they want some guarantee and stability.

Attitude to the war is characterized by fear, threat, destroyed plans. IDPs mostly marked the concept "War" in black colour (60\%). These attitudes are explained through concepts that are marked in the same colour. The war is associated with emotional experiences "Fear" and "Threat". Migrants have a period of adaptation to a new home, work, educational institution caused by radical changes in their life. This period is unpredictable and complex, radically different from the past, determined by new needs, 
goals, and motives; but IDPs associate their future life rather with negative experiences and small hope.

The gender specificity of the subjective attitudes of IDPs has been revealed. Female respondents marked the concepts "My future" (45\%) and "Who I want to be" $(36,3 \%)$ in one colour (green), which caused by their orientation towards the future and the formation of their image of "I" in this future. Also, the concepts "Financial support" $(54,5 \%)$ and "Financial well-being" (63,6\%) were marked in green colour. The concepts "Legal advice" (54,5\%), "Politics" (63.6\%), "Uncertainty" (54,5\%) and "Sadness" (54,5\%) were marked in grey colour. The political situation causes negative attitudes, uncertainty, and confusion which actualize legal advice for IDPs. It should be noted that female respondents didn't mark the concept "War" in one colour, which means differentiated attitude and a wide range of experiences, connected with this concept.

Male respondents marked the concept "Who I want to be" $(35,7 \%)$ in green colour. It is associated with the concepts "Communication" (35,7\%), "Career" (35,7\%) and "Selfrespect" (35,7\%). Respondents feel their own "Ideal I" positively; associate the future with career growth, self-respect, communication with other people. Men who are at the adaptation stage, but found work and orient towards development in this area, are making a lot of efforts for career growth.

The concepts "Stability" (35,7\%) and "Earnings" (42,8\%) were marked in red colour and associated with other concepts as "Aggressor" (35,7\%) and "Aggressiveness" (42,8\%). That is, financial support and a stable life are currently relevant for men; they want to improve them in the future.

The results of our empirical study confirmed other scientific data on the gender specificity of the subjective attitudes of IDPs.

\section{Conclusion}

Subjective attitude as the integral features of the personality is the basis of subjective well-being. They determine the success of the psychological adaptation of IDPs. Successful social and psychological adaptation of the IDPs takes place in the conditions when the social environment helps to uncover them potential, and if the requirements and expectations of a participant of social interaction (IDPs and the host community) are agreed. Other important factors are the normalization of the psychological and emotional state of migrants; the overcoming of stress disorders through the identification and involvement of all personal resources to overcome the difficult adaptation period; the development of a positive attitude to activities, other people, themselves and life in general.

Psychological peculiarities of the system of emotional attitudes of IDPs have been empirically revealed. Young people have rather high indicators of psychological adaptation. This category of IDPs feels psychological well-being and capable to overcome life difficulties. The analysis of rating of the concepts may it possible to reveal the highest average ratings and ranking positions of the concepts "My home", "Optimism"”, "Joy", "Real I", "Ideal I", "Confidence", "Guarantees", "Financial well-being" which mean the positive attitude of IDPs to these concepts and confidence in their capabilities, and the aspiration for self-realization. Key concepts "Politics", "War", "Displacement" have the lowest average ratings and ranking places. They are relevant with different negative emotional states, such as, "Pain", "Anxiety", "Loneliness", "Threat", and "Fear".

The gender specificity of the structure of the attitudes of IDPs has been determined. Men are more aware of their ability to solve complex life problems; satisfied with business relations; focused on activities and aspiration for self-realization in the business sphere. 
They have a high level of emotional stability. Women are satisfied with relationships in the informal sphere. They are more focused on family relationships.

The prospect of further studies relates to the study of the age specificity of attitudes of IDPs through research and comparison of different age groups of migrants: childrenschoolchildren, young people, and elderly people.

\section{References}

Balabanova, L. M. (2017). Psychological peculiarities of the reflexion of forced migrants. Problems of extreme and crisis psychology. Vol. 22. 51-59 [in Ukrainian].

Berry, J.W. (1997). Immigration, acculturation and adaptation. Applied Psychology: International Review. Vol. 46 (1). 5-34.

Blynova, O. E. (2016). Social and psychological principles of the adaptation of forced migrants. Actual problems of psychology: a collection of scientific works of G.S. Kostiuk Institute of Psychology of NAPS of Ukraine. Vol. IX: General Psychology. Historical psychology. Ethnic psychology. Issue 9. Kyiv: Talkom. 58-66 [in Ukrainian].

Blynova, O. E. (2018). Socio-psychological problems of the host community's attitude to forced migrants. Scientific Bulletin of Kherson State University. Series «Psychological Sciences». 2017. Vol. 3 (2). 136-141. [in Ukrainian].

Chenbay, I. V. (2015). Areas of activity of organizations of the social sphere on the assistance of internally displaced people. The Announcer of Cherkasy University. No. 37 (370). 128-133 [in Ukrainian].

Furnham, A., Bochner, S. (1994). Culture Shock: Psychological reactions to unfamiliar environments. L. \& N.Y.

Lazos, H. P. (2015). Psychological helping to internally displaced persons (for example, on work with migrants from the Crimea). Psychological helping for victims of crisis traumatic events: methodical manual. Kyiv: Logos. 26-46 [in Ukrainian].

Leonova, I. M. (2015). Theoretical analysis of problems of social and psychological adaptation of forced migrants in Ukraine. Actual problems of sociology, psychology, pedagogy. No. 4 (29). 94-100 [in Ukrainian].

Maksimova, N. A. (2014). Methodical recommendations on the organization and provision of psychological assistance to children and families of internally displaced persons. Informational and methodical collection. Belaya Tserkov: KOIPOPK. No. 9. 3952 [in Ukrainian].

National Monitoring System Report on the Situation of Internally Displaced Persons. (December, 2018). Retrieved from: https://cutt.ly/eLlqX0 [in Ukrainian].

Orban-Lembryk, L. E. (2008). Influence of migration processes on behavioral manifestations of personality. Collection of scientific works: philosophy, sociology. Ivano Frankivsk: VDV TCIT. Vol.13 Part 1. 3-15 [in Ukrainian].

Slyusarevskyi, M. M, Blynova, O. E. (2013). Psychology of migration. Kirovograd: "Imex LTD" [in Ukrainian]. Russian].

Solomin, I. L. (2008). Express-diagnostics of personality. Sankt-Peterburg: Rech [in

Tytarenko T. M. (ed.) (2011). Prevention of violations of youth adaptation to everyday stresses and crisis life situations: a manual. Kyiv: Millennium [in Ukrainian].

Uvarova, S., Pylypenko, N., Ulko, N., et al. (2014). Social and psychological assistance to children and their families, a temporary movement to the regions of Ukraine from the temporarily occupied territory and areas of anti-terrorist operation: practical management of psychologists and social workers. Kiev [in Ukrainian]. 


\section{ДІАГНОСТИКА ПСИХОЛОГІЧНИХ ОСОБЛИВОСТЕЙ ЕМОЦЙНИХ СТАВЛЕНЬ ВНУТРІШНЬО ПЕРЕМЩЩЕНИХ ОСІБ}

Ярослава Василькевич, кандидат психологічних наук, доиент, доиент кафедри психологї ДВНЗ «Переяслав-Хмельницький державний педагогічний університет імені Григорія Сковороди», вул. Сухомлинського, 30, Переяслав-Хмельницький, Україна, 08401, v.yaroslava@online.ua

Анотація. $У$ роботі теоретично визначено психологічну складову адаптації вимушених переселенців, схарактеризовано індивідуальні та групові чинники соиіально-психологічної адаптащії. Обтрунтовано вплив на адаптащію суб'єктивних ставлень як інтегральної особистісної характеристики переселенців, які $\epsilon$ основою суб'єктивного благополуччя та детермінують успішність психологічної адаптаиії внутрішньо переміщених осіб. Розроблено та адаптовано для вибірки вимушених переселенців методику колірних метафор, яка дозволяє діагностувати реальні мотиви, справжні переживання, усвідомлені та неусвідомлені ставлення людини до себе, інших людей та організацій, подій і різних видів діяльності. Емпірично виявлено психологічні особливості системи емоційних ставлень внутрішньо переміщених осіб. Аналіз рейтингових оцінок понять виявив найвищі усереднені рейтингові оцінки та відповідно рангові місия у понять «Мій дім», «Оптимізм», «Радість», «Я Реальне», "Я Ідеальне», «Впевненість», «Гарантії》, «Матеріальне благополуччя», ще свідчить про позитивне ставлення внутрішньо переміщених осіб до иих понять та означає впевненість у своїх можливостях і прагнення до самореалізації. Ключові поняття «Політика», «Війна», «Переселення» мають найнижчі усереднені рейтингові оиінки й рангові місия та супроводжуються негативними емоційними станами "Біль», «Тривога», «Самотність», «Загроза», «Cтрах».

Визначено гендерну специфіку структури ставлень вимушених переселенщуів (встановлено вищий рівень емоџійної стабільності та самооцінки у чоловіків, які більще задоволені стосунками у діловій сфері та мають спрямованість на діяльність; жінки виявляють задоволеність стосунками у неформальній сфері та більш спрямовані на сім'ю).

Зроблено висновки, що вимушеним переселенцям віку ранньої зрілості притаманні достатньо високі показники психологічної адаптації, саме ия категорія внутрішньо переміщених осіб відчуває психологічне благополуччя та вважає себе здатною долати життєві труднощі.

Ключові слова: внутрішньо переміщені особи; соціально-психологічна адаптаичія; емоиійні ставлення.

\section{Література}

Балабанова, Л. М. (2017). Психологічні особливості рефлексії вимушених переселенців. Проблеми екстремальної та кризової психології, (22). С. 51-59.

Блинова, О. Є. (2017). Соціально-психологічні особливості ставлення приймаючої спільноти до вимушених переселенців. Науковий вісник Херсонського державного університету. Серія Психологічні науки, (3). Т. 2. С. $136-141$. 
Блинова, О. С. (2016). Соціально-психологічні засади адаптації вимушених мігрантів. Актуальні проблеми психології: збірник наукових праць Інституту психології імені Г.С. Костюка НАПН України. Том IX: Загальна психологія. Історична психологія. Етнічна психологія. Випуск 9. Київ: Талком, C.58-66.

Звіт Національної системи моніторингу ситуації 3 внутрішньо переміщеними особами. Грудень 2018 р. - [Електронний ресурс]. http://iom.org.ua/sites/default/files/nms round $12 \mathrm{ukr}$ screen.pdf

Лазос, Г. П. (2015). Психологічна допомога внутрішньо переміщеним особам (на прикладі роботи з переселенцями з Криму). Психологічна допомога постраждалим внаслідок кризових травматичних подій : метод. посіб. Київ : Логос, С. 26-46.

Леонова, I. М. (2015). Теоретичний аналіз проблеми соціальнопсихологічної адаптації вимушених переселенців в Україні. Актуальні проблеми соиіології, психології, педагогіки. №4 (29). С. 94-100.

Максимова, Н. А. (2014). Методичні рекомендації щодо організації та надання психологічної допомоги дітям та сім'ям вимушених переселенців. Інформачійно-методичний збірник. Біла Церква : КОІПОПК, № 9. С. 39-52.

Орбан-Лембрик, Л. Е. (2008). Вплив міграційних процесів на поведінкові прояви особистості. Збірник наукових пращь: філософія, соџіологія, психологія. ІваноФранківськ : ВДВ ЦІТ, Вип.13. Ч.1. С. 3-15.

Профілактика порушень адаптації молоді до повсякденних стресів i кризових життєвих ситуацій : навч. посіб. / Нац. Акад.. ед.. наук України, Ін-т ед.. та політ. психології ; за наук. ед.. Т. М. Титаренко. Київ : Міленіум, 2011. 272 с.

Слюсаревський, М. М., Блинова, О.Є. (2013). Психологія міграції. Кіровоград : ТОВ «Імекс ЛТД», 244.

Соломин, И. Л. Экспресс-диагностика персонала. СПб.: Речь, 2008. 280 с.

Соціально-психологічна допомога дітям та їхнім сім'ям, тимчасово переміщеним в регіони України 3 тимчасово окупованих територій і районів проведення антитерористичної операції : практичне керівництво для психологів та соціальних працівників / С. Уварова, Н. Пилипенко, Н. Улько та ін.]. Київ, 2014. 106.

Ченбай, І. В. (2015). Напрями діяльності організацій соціальної сфери 3 допомоги внутрішньо переміщеним особам. Вісник Черкаського університету. № 37 (370). C. 128-133.

Berry, J. W. (1997). Immigration, acculturation and adaptation. Applied psychology: An international review. Vol. 46 (1). P. 5-34.

Furnham, A., Bochner, S. (1994). Culture Shock: Psychological reactions to unfamiliar environments. L.\& N.Y., 240. 